\title{
THE UNSUSTAINABILITY OF PUBLIC-SECTOR ORGANIZATIONAL
} NETWORKS: A CASE STUDY OF VOLUNTARY COURT NETWORKS

\author{
Przemysław BANASIK ${ }^{1}$, Monika ODLANICKA-POCZOBUTT ${ }^{2}$, Sylwia MORAWSKA ${ }^{3 *}$ \\ ${ }^{1}$ Gdańsk University of Technology, Wydział Zarządzania i Ekonomii, Katedra Przedsiębiorczości i Prawa \\ Gospodarczego; przbanas@pg.edu.pl, ORCID: 0000-0002-9231-6066 \\ ${ }^{2}$ Silesian University of Technology, Department of Organization and Management, Institute of Management and \\ Logistics; monika.odlanicka-poczobutt@polsl.pl, ORCID: 0000-0001-7834-1188 \\ ${ }^{3}$ SGH Warsaw School of Economics Collegium of Business Administration Department of Administrative and \\ Financial Law of Enterprises; smoraw@sgh.waw.pl, ORCID: 0000-0001-6708-338X \\ * Correspondence author
}

Purpose: The purpose of this study is to identify the problem of sustainability of public-sector organizational networks on the example of common courts and what it implies for further research. Methodology: The study used qualitative research tools in the form of structured interviews. Interviews were conducted with 36 presidents and directors of common courts. After conducting and transcribing each interview, their content was analyzed to capture data related to network durability. Based on the proposed methodology, 5 elements of network sustainability were distinguished: goal continuity, reliability, communication, network capability, fairness.

Findings: It was found that the judiciary has the potential to take advantage of network cooperation mechanisms, which may involve different relationships and interactions. However, after the pilot project, voluntary court networks formed during the implementation of the project gradually dissolved, ceased to exist. The identification of the elements of network was an additional outcome of the analysis of the results of a pilot study PWP Edukacja w dziedzinie zarządzania czasem i kosztami postępowań - case management.

Originality/value: Research on the networking of public organizations, and in particular common courts, is still a cognitive gap. The results of research carried out for the purposes of the article are trying to fill this gap. within the study, the causes of failures in maintaining network relationships in common orchards were identified.

Keywords: network, public-sector organizations, common courts, elements of network sustainability, organizational justice, antecedences of the instability. 


\section{Introduction}

The 21 st century in management sciences has been the time of network organizations supported by information technologies, offering new opportunities for joint creation and exchange of knowledge, skills and abilities between partners. Process instrumentation is the main method of managing a network organization. When applying the network approach, organizations must put emphasis on cooperation within the network, thus giving up the strict focus on their own business. Cooperation with the environment, the need for knowledge and exchange of information, is also very important in this process. Current tech and IT solutions make it possible to search for useful resources within the network.

Members of an organizational network can work together to pursue joint ventures and innovative activities, use different unique abilities, as well as forge specialized relationships of skills deployed across various organizations in the network. Cooperation within this structure helps get access to new knowledge resources through the development of learning processes from other members of the organization; gain better skills and abilities to solve complex social and business problems in teams, also through the better understanding of challenges awaiting the organization (Tubielewicz, 2013).

The architecture of public-sector organizational networks gives the possibility of: internal and external harmonization of a set of many correlations, introducing a new code of conduct, maintaining and expanding the layout of sustainable interpersonal relations, and building new knowledge. When speaking of public-sector organizational networks in this article, we will refer to courts acting on the basis of a specific legal framework (Act on Common Courts Organisation, 2001) that approaches the concept of network from several perspectives. This is due to the multiplicity of interested parties who may define network goals and assess network results in a different way. There is a clear need to create open networks, sensitive to changes and ready to deal with environmental challenges.

The purpose of this study is to identify the problem of sustainability of public-sector organizational networks on the example of common courts and what it implies for further research. The 5 elements of network sustainability are discussed in the following section.

The identification of the elements of network was an additional outcome of the analysis of the results of a pilot study on the implementation of modern methods of management of common courts, carried out as part of PWP Edukacja $w$ dziedzinie zarzadzania czasem i kosztami postepowań - case management [PWP Education in the field of time management and costs of proceedings - case management].

Among the elements pointing to an antecedent of instability in court networks, there were the lack of the continuity of goals and organizational justice in terms of division, rules and information after the pilot project was completed. 


\section{Literature review}

\subsection{Network concept}

A network is a set of entities and the relatively sustainable ties between them. There is a number of definitions, typologies and problems related to the concept of 'network' (Knop, Odlanicka-Poczobutt, 2016). Network architecture - understood as a web of external and internal ties, as well as contacts and contracts concluded within it - is important, as it enables the integration and coordination of a wide variety of organizations and it also helps create and exchange new knowledge, experience and skills by adding value to the links and processes of the value chain and supply chain (Odlanicka-Poczobutt, 2016).

A network is mainly defined by cooperative ties, the strength of which relies on trust and long-term contracts (Odlanicka-Poczobutt, 2011a). A network may be a system organized by enterprises that are financially independent from or slightly correlated with each other. It may also exist in a capital group, or even in a single company (Nogalski, Dwojacki, 1998). These connections bring external effects to organizations. A network effect is when the value of a good increases along with the amount of sales of this good to specific buyers. The higher the number of users, the greater the value of the product (Stabryła, 2012). Complex structures involve many links in the cooperation chain. These are the typical structures applicable on the B2B (business-to-business) market (Odlanicka-Poczobutt, 2011b).

A network organization is therefore based on joint ties of financially independent enterprises and these connections rely on cooperation, most often carried out under contracts (medium-term and long-term). The definitions presented in the literature refer mostly to enterprises, whereas public-sector organizations and the way they are managed have remained outside the scope of interest in a dynamically developing science and practice of management in this area (Kieżun, 2012; Kożuch, 2004; Lissowski, 2014; Mazur, Olejniczak, 2012). In recent years, however, there has been an increased demand for this type of studies as part of the emerging break-away discipline of management sciences - public management (Mazur, 2015; Izdebski, 2007; Zawadzak, 2014; Cyfert, Dyduch, Latusek-Jurczak, Niemczyk, Sopińska, 2014).

\subsection{Network cooperation mechanisms in the judiciary}

Studies on the behavior of public organizations in Poland and in the world tend to focus on public administration (state government and local government), schools or healthcare organizations (Frączkiewicz-Wronka, 2006). Thus, there is a cognitive gap regarding the functioning of public-sector organizational networks, as opposed to the legal definition that perceives a public network as a telecommunications network that is not an internal network and that is there to provide publicly available telecommunications services (Telecommunications Act, 2004). 
In this article we will refer public-sector organizational networks to courts acting on the basis of a specific legal framework (Act on Common Courts Organisation, 2001) that approaches the concept of network from several perspectives. This is due to the multiplicity of interested parties who may define network goals and assess network results in a different way. These perspectives can be put forward by individual members, networks and the public (Odlanicka-Poczobutt, 2013). As far as the public is concerned, it is important for a network to be useful to the community it is intended to serve, which can be understood, primarily, as improving the quality and accessibility of services provided within that network. In a network resulting from the position of a court in the hierarchy (district court, regional court, court of appeal), an analysis can be carried to measure the distribution of burden among its members. In turn, a level of organization means focusing on the results achieved by individual members of the network (Provan, Milward, 2001), given that courts differ in both tangible resources (depending on size) and intangible resources: knowledge and skills of employees, organizational culture, ability to learn, reputation, a network of contacts (Banasik, Brdulak, 2015, Banasik, Morawska, 2016, Banasik, Majchrzak, 2015). Courts are embedded in a dense structure of ties with the environment (Czakon, 2017), including with other courts.

In the judiciary, there is a potential to use network cooperation mechanisms in which various relationships and interactions may occur (Banasik, 2015). Interorganizational cooperation is possible in both ancillary and base court activities. Cooperation in base (adjudicative) activities requires conducting separate, in-depth studies. Interorganizational networking in base activities could consist in reaching a consensus within interpretative views on civil, criminal, economic and other cases, in horizontal arrangements within a district or an appeal, thereby building trust in the justice system. As far as ancillary activities, the creation of interorganizational ties will primarily serve the transfer of good managerial and organizational practices (Banasik, Morawska, 2015; Kuczewska, Morawska, 2015; Morawska, Kuczewska, 2016; Banasik, 2016).

\subsection{Advantages of the voluntary network as a network organization}

Studies conducted in the polish judiciary show that judicial cooperation is indeed possible, cross-cutting hierarchical subordination, as part of heterarchical relationships, as a voluntary interorganizational network (Banasik, Kuczewska, Odlanicka-Poczobutt, Morawska, 2017).

A pro-innovation cooperation within the network and creating new intellectual resources also offer much greater opportunities (Koćwin, 2013). As part of heterarchical voluntary networks, courts may exchange good managerial and organizational practices. Cooperation within the network may also help improve organizational efficiency in common courts through a rational use of resources and a balanced cooperation of all elements of the organization. A voluntary network was established between the courts during the pilot project, which served to exchange knowledge between individual entities and come up with solutions to improve management. It also provided a platform for sharing good practices in the area of substantive 
activities, which is consistent with Mandell and Keast (2008), who argue that the principal objective of a network is to connect its members, facilitate common activities and learning, and consequently, create new solutions to existing problems.

Interorganizational networks take the form of complex multi-entity structures with varying degrees of durability, consistency and openness (Lichtarski, 1993). According to the dictionary, the term sustainability is synonymous with: durability, constancy, invariability, continuity, permanence, immutability, irreversibility, impassability, immortality, strength, stability, endurance, reliability, resistance, stiffness, indestructibility, indissolubility (http://www.synonyms.pl/synonim/trwalosc).

In traditional companies, network sustainability depends on proprietary connections, guaranteeing at least a minimum supervision over the activities of partners (through participation in general meetings or supervisory boards). Intensification of proprietary links between cooperating partners may result in mergers and acquisitions, at which time holdings or separate associated companies are formed. This is to say: there are centripetal (centralist) trends at work. Centrifugal (decentralist) trends occur when any of the participants in the system begins to perceive their position and situation as not quite favorable, not fully corresponding to their aspirations. They then start to seek alternative options of action (diversification of supplies or recipients) (Dwojacki, 1995; Nogalski, Dwojacki, 1998).

\section{Material and methods}

Networking, as a variable describing processes in the global economy, is not directly correlated with sustainability, stability and durability, if only because of the dynamics of the environment (Cyfert, Krzakiewicz, 2014). Taken together, these issues form a new field of research: whether and how a network can be sustainable. Network sustainability can be understood as a relatively long duration of the possibility of achieving the network's goals (Borczuch, Czakon, 2005). Recent studies are increasingly focused on the search for the ability to successfully manage constant change, rather than stability. Therefore, management is organized around the network, instead of the hierarchy, and relies on partnerships and alliances, instead of self-sufficiency (Szplit, Szplit, 2014).

The purpose of this study is to identify the problem of sustainability of public-sector organizational networks on the example of common courts and what it implies for further research. Based on the methodology proposed in Antecedencje i konsekwencje trwałości sieci - podstawowe założenia badawcze [Antecedents and consequences of network sustainability basic research assumptions], 5 elements of network sustainability were distinguished: 
1. the continuity of goals,

2. reliability,

3. communication,

4. the ability to serve the network,

5. justice (fairness) (Knop, Odlanicka-Poczobutt, 2016).

These elements are discussed in the following section, indicating antecedents of the identified unsustainability in court networks resulting from the approach adopted.

The continuity of goals implies being embedded in the economic reality, which requires a confirmation of participation in the cooperation network, with no room for anonymity and the need for clear determination of cooperation terms on the part of individual participants. The basis of network operation is collaboration, the ability to share resources, and ideally, finding a goal whose joint pursuit will safeguard the continuity of cooperation.

Reliability in a network determines the ability of participants to froge the right relations with the environment. Organizations that work with identified interested parties and maintain relationships with them generally fare better at managing and counteracting potential crisis situations. A good knowledge of the key environment translates into a more effective relationship that is shared with it.

A network could not function without communication, or better yet, an agreement to use a common communication tool chosen by means of consensus. The ability to serve the network is related to the efficiency and effectiveness of cooperation, while the key to effective cooperation is organizational justice (Turek, 2011) in terms of division, rules and information.

Modern philosophers assume that fair and just is what is consistent with previously adopted formal rules (Bernatt, 2011). Justice springs from contemporary philosophical and political concepts of Rawls, Nozick and Sen on the one hand, and on the other hand, from the analysis of social phenomena, including Blau's theory of "social exchange", Adams' "equality", Homas' distributive justice, Thibaut and Walker's procedural justice, Linda and Tyler's group value theory, or last but not least, Stouffer's and others' studies from the 1940s (Colquitt, 2008).

Figure 1 shows the constituent elements of organizational justice, consisting of: distributive, procedural and information justice. Distributive justice is defined as a sense of balance related to the distribution of prizes/bonuses, resulting from a comparison of individual effort or resources invested with the effort and resources of other people. Procedural justice describes the process (set of rules) of resource allocation in the organization as perceived by the entity (Greenberg, 2009).

Networks can therefore be more effective when they perceive their organization as just and when a friendly, trust-based atmosphere is created that enables cooperation and sharing of knowledge (Turek, 2011; Karriker, 2007). 


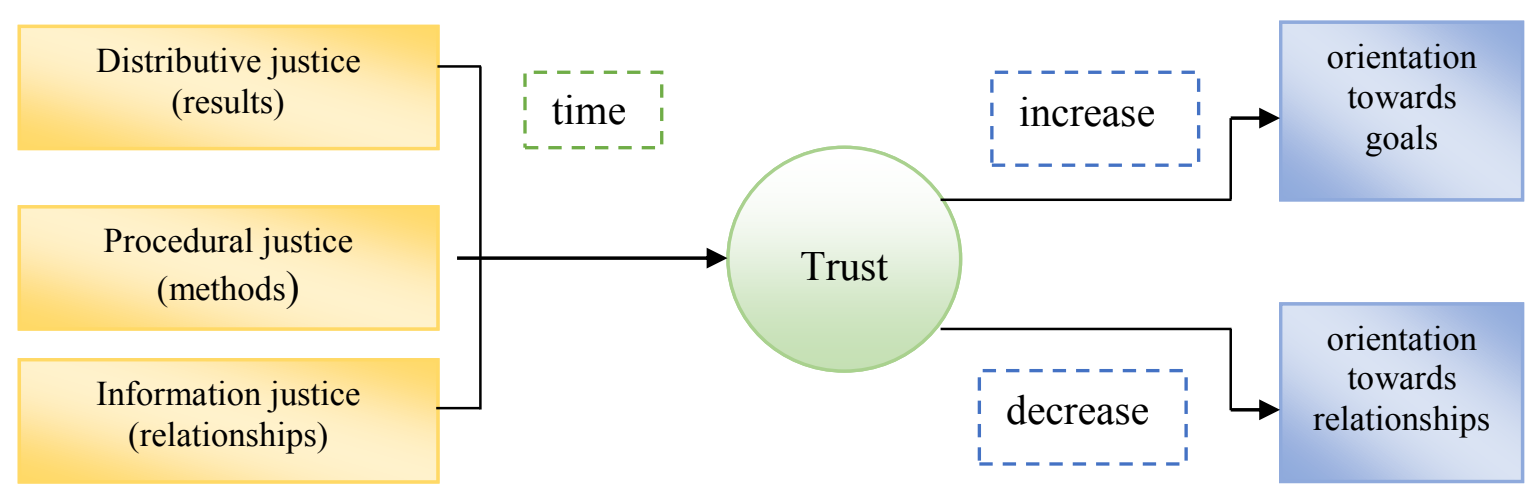

Figure 1. Organizational justice and job performance. Source: (Wagner, Hollenbeck, 2010).

The identification of the elements of network was an additional outcome of the analysis of the results of a pilot study on the implementation of modern methods of management of common courts, carried out as part of PWP Edukacja $w$ dziedzinie zarzadzania czasem $i$ kosztami postepowań - case management [PWP Education in the field of time management and costs of proceedings - case management], which prompted further studies on networking in common courts. Nearly $10 \%$ of all courts in Poland were sampled. When screening the sample, the diversification of the set of empirical examples was used with a view to provide a better identification of the studied area and a better implementation of research objectives. 36 courts at different hierarchy levels and of different size participated in the study. Courts were selected based on the following criteria: participation in the pilot implementation of modern methods of management of common courts, court activity in identification and subsequent development of good management and organizational practices to be implemented in other participating courts, and finally, initiating meetings of court representatives.

The number of cases covered by the study was set arbitrarily, seeking to capture examples in which trials and processes studied occur very clearly, with both positive and negative outcomes. To capture the full variation, a test procedure based on sample size saturation was used (Babbie, 2003). After conducting and transcribing each interview, their content was analyzed to capture data related to sustainability of networks. Data analysis began immediately after data collection was completed, which allowed researchers to consolidate each subsequent stage of the study. Social network analysis (SNA) was carried out in the study using the Gephi software. By the way - the resulting network was also mapped based on the analysis of meeting protocols. It consisted of 64 actors and 6,492 relationships established between them. 


\section{Results and discussion - the determinants of insustaibability in public- sector organizational networks}

This pilot study found that voluntary court networks formed during the implementation of the project gradually dissolved, ceased to exist. It was conditioned, among other factors, by changes on the positions of CEO (due to expiration of term) and Court Manager, which prompted courts to withdraw from the voluntary network.

With reference to the assumptions that network sustainability is expressed in the continuity of goals, reliability, communication, the ability to serve the network and justice (fairness), it should be considered which - and how many - of these elements point to antecedents of the instability in court networks.

The completion of the pilot project was probably the reason why the network dissolved, given that there was no longer a platform for joint actions. Although study subjects emphasized the advantages of interorganizational cooperation, the network dissolved anyway, which suggests the loss of the continuity of goals may be to blame. The termination of the project resulted in the lack of need for confirmation of participation in the cooperation network and the lack of clear determination of the terms of cooperation of individual participants.

Reliability of the network, determining the ability of entities to forge the right relations with the environment, was not lost, whereas communication, involving the use of a common tool chosen by reaching a consensus, was shaken. Courts retain formal and legal independence while in the network. It seems that courts and their CEO may play the role of a launcher, but conducting a network in the case of a voluntary heterarchical network requires codetermination on the part of participants. In these networks, leadership is shaped by the mutual activities of network participants (Müller-Seitz, 2012). Studies show that the presence of an external entity - in this case: the National School of Judiciary and Publish Prosecution (KSSR) - was an important communication tool for the functioning of voluntary court networks. Respondents stated that the role of that entity should involve network administration and provision of knowledge bases, although in reality, KSSR played the role of an initiator in the network. Further initiatives in this area could revive the voluntary network in a similar or different arrangement. Network administration or provision of knowledge bases can be implemented in the network through the actors themselves - courts can potentially carry out these tasks, both in a centralized and dispersed way.

The ability to serve the network, related to the efficiency and effectiveness of cooperation, should remain unchanged because the courts declared willingness to participate in projects in the future, appreciating the advantages and validity of such initiatives for organizational development. The gradual 'withering' of the network following the pilot project suggests a clear 
need for the existence of a facilitator ${ }^{1}$ (Pniewski, Bagińska, 2013), although it seems to be mainly due to direct relationships based on personal connections (Banasik, Kuczewska, Odlanicka-Poczobutt, Morawska, 2017).

Paradoxically, an element that probably was not met either and that could determine dissolution was the lack of organizational justice in terms of division, rules and information after the pilot project was completed. As long as there were formal regulations defining the roles of project participants, each participant knew what their tasks were. Network initiators were 11 CEOs of common courts participating in the project, although the network itself was dispersed - none of the CEOs wanted to assume leadership, as it went beyond their legal competences regulated under the Act on Common Court Organisation. The gradual dissolution of the network following the pilot project suggests a clear need for the existence of a leader, rather than a facilitator, due to the occurrence of direct relations based on personal connections. In a heterarchical network, a leader can potentially influence individual network members, but their position does not pose a threat to the hierarchical system as such. Certainly, it requires setting rules, further division of roles and terms of information flow, while being a serious managerial challenge outside the formal boundaries of one court.

Networking in common courts should ensure complementarity, understood as bringing to the network unique, supplementary and relevant resources by each of its members. It should also ensure that members are mutually compatible in terms their work style, and determine cooperation terms between members by creating clear standards for the implementation of tasks and contribution to objectives. The basis will also be maintaining and verifying new and existing principles of network operation on an ongoing basis.

It is worth noting that all these factors can translate into the speed of action, that is, the shortest possible time of response of an organization to an occurring change. This is precisely where the strength of a network lies -its effectiveness and efficiency depends on the performance of all links, making a rapid flow of information and materials within the existing network a very important issue (Odlanicka-Poczobutt, 2016).

\section{Conclusions}

The emergence of new structures, such as intra- and interorganizational networks, is associated with profound changes. Creating modern, flexible solutions in place of hierarchical structures gives organizations the opportunity to increase operational excellence. It also enables more effective learning, and helps avoid barriers, minimize risks and reduce uncertainty.

\footnotetext{
${ }^{1}$ Facilitator - a person whose task is to actively participate in the clearing of communication between individuals or groups in order to arrive at a common solution.
} 
The purpose of this study was to identify the problem of sustainability of public-sector organizational networks on the example of common courts and what it implies for further research. Public-sector organizational networks were understood as courts acting on the basis of a specific legal framework that can be considered a network from the point of view of individual members, networks and the public.

Based on the proposed methodology, 5 elements of network sustainability were distinguished: the continuity of goals, reliability, communication, the ability to serve the network, justice (fairness). It was found that the judiciary has the potential to take advantage of network cooperation mechanisms, which may involve different relationships and interactions. However, after the pilot project, voluntary court networks formed during the implementation of the project gradually dissolved, ceased to exist. Among the elements pointing to an antecedent of instability in court networks, there were the lack of the continuity of goals and organizational justice in terms of division, rules and information after the pilot project was completed.

The termination of the pilot study was probably the reason why the network dissolved, given that there was no longer a platform for joint actions (initiated by KSSP that proved a good external initiator). Despite the advantages of networking, the network ceased to exist, although further initiatives may revive the voluntary network in a specific arrangement.

A good solution would be for network participants to consider establishing a set of common goals to be pursued outside of the project initiatives launched by external entities, which would help sustain reliability, communication and the ability to serve the network.

Unsustainability in public-sector organizational networks is an interesting research topic, but it requires further in-depth studies, especially in other public organizations outside the judiciary. The current state of knowledge in this area certainly cannot be considered satisfactory and requires further testing.

\section{References}

1. Babbie, E. (2003). Badania społeczne w praktyce. Warsaw: PWN.

2. Banasik, P. (2015). Organizacja wymiaru sprawiedliwości w strukturze sieci publicznej możliwe interakcje. E-mentor, 2(59).

3. Banasik, P. (2016). Sąd zaangażowany społecznie. Pożąany kierunek zmian. Warsaw: Oficyna Wydawnicza SGH.

4. Banasik, P., Brdulak, J. (2015). Organisational culture and change management in courts, based on the examples of the Gdańsk area courts. International Journal of Contemporary Management, 14, 33-50. 
5. Banasik, P., Kuczewska, J., Odlanicka-Poczobutt, M., Morawska, S. (2017). Współpraca sieciowa sądów w Polsce. Zeszyty Naukowe Wyższej Szkoły Ekonomiczno-Społecznej w Ostrołece, 3(26), 108-127.

6. Banasik, P., Majchrzak, K. (2015). Budowa wizerunku wymiaru sprawiedliwości. Zeszyty Naukowe Uniwersytetu Szczecińskiego. Problemy Zarządzania, Finansów i Marketingu, 41(1), 339-349.

7. Banasik, P., Morawska, S. (2015). Usieciowienie wymiaru sprawiedliwości a wyzwania dla kadry zarządzającej. Edukacja Ekonomistów i Menedżerów: problemy, innowacje, projekty, 3(37).

8. Banasik, P., Morawska, S. (2016). The Courts' Public Image-The Desired Direction of Change. International Journal for Court Administration, 8, 2-11.

9. Bernatt, M. (2011). Sprawiedliwość proceduralna w postępowaniu przed organem ochrony konkurencji. Wydawnictwo Naukowe Wydziatu Zarzadzania Uniwersytetu Zarzadzania, 31. Warsaw.

10. Borczuch, A., Czakon, W. (2005). Trwałość sieci gospodarczych w świetle teorii gier. Przegląd Organizacji, 3.

11. Colquitt, J.A. (2008). Two Decades of Organizational Justice: Findings, Controversies and Future Directions. In: J. Barling, C.L. Cooper (eds.), Organizational Behavior. Micro Approaches (73). London: Sage.

12. Cyfert, Sz., Dyduch, W., Latusek-Jurczak, D., Niemczyk, J., Sopińska, A. (2014). Subdyscypliny w naukach o zarządzaniu - logika wyodrębnienia, identyfikacja modelu koncepcyjnego oraz zawartość tematyczna. Organizacja i Kierowanie, 1(161).

13. Cyfert, Sz., Krzakiewicz, K. (2014). Granice w świecie sieciowych i wirtualnych organizacji. In: A. Sopińska, S. Gregorczyk (eds.). Granice strukturalnej złożoności organizacji (pp. 47-62). Warsaw: Oficyna Wydawnicza Szkoły Głównej Handlowej.

14. Czakon, W. (2007). Dynamika więzi międzyorganizacyjnych przedsiębiorstwa. Katowice: Wydawnictwo Akademii Ekonomicznej im. Karola Adameckiego.

15. Dwojacki, P. (1995). Sieć organizacyjna jako wynik przekształceń w strukturze przedsiębiorstwa. In: Zarządzanie przedsiębiorstwem $w$ warunkach transformacji gospodarki. Jurata: materiały konferencyjne Polskiej Akademii Nauk i Uniwersytetu Gdańskiego.

16. Frączkiewicz-Wronka, A. (2006). Koncepcja sieci w zarządzaniu systemem ochrony zdrowia w regionie - raport z badań. In: Z. Kędzior, G. Musiał, H. Brandenburg (eds.), Ekonomia. Kierunki badań (pp. 56-70). Katowice: Wydawnictwo Uczelniane Akademii Ekonomicznej.

17. Greenberg, J. (2009). Everybody Talks About Organizational Justice, But Nobody Does Anything About It. Industrial and Organizational Psychology, Vol. 2, 181-195.

18. http://www.synonimy.pl/synonim/trwałość. 
19. Izdebski, H. (2007). Kierunki rozwoju zarządzania publicznego w Europie. In: H. Izdebski, H. Machińska (eds), W poszukiwaniu dobrej administracji. Warsaw: Wydział Prawa i Administracji UW.

20. Karriker, J. (2007). Justice as Strategy: the Role of Procedural Justice in an Organizational Realignment. Journal of Change Management, Vol. 7, No. 3-4, 329-342.

21. Kieżun, W. (2012). Polski dorobek teoretyczny zarządzania publicznego. Współczesne Zarządzanie, 2(202).

22. Knop, L., Odlanicka-Poczobutt, M. (2016). Antecedencje i konsekwencje trwałości sieci podstawowe założenia badawcze. In: C. Suszyński, G. Leśniak-Łebkowska (eds.), Organizacja inteligentna. Perspektywa zasobów ludzkich (pp. 415-430). Warsaw: Szkoła Główna Handlowa - Oficyna Wydawnicza.

23. Knop, L. Odlanicka-Poczobutt, M. (2016). W sieci sieci. In: S. Gregorczyk, W. Mierzejewska (eds.), Zarządzanie przedsiębiorstwem inteligentnym. Wybrane zagadnienia (pp. 471-490). Warsaw: Szkoła Główna Handlowa - Oficyna Wydaw.

24. Koćwin, P. (2013). Organizacja sieciowa. Perspektywa semantyczna. Zeszyty Naukowe Wyższej Szkoły Bankowej w Poznaniu, 49, 103-117.

25. Kożuch, B. (2004). Zarządzanie publiczne w teorii i praktyce polskich organizacji. Warsaw: Agencja Wydawnicza Placet.

26. Kuczewska, J., Morawska, S. (2016). Court Excellence Model jako narzędzie poprawy sprawności organizacyjnej sądów. Prace Naukowe Uniwersytetu Ekonomicznego we Wrocławiu, 439, 206-218.

27. Lichtarski, J. (1993). Współdziałanie gospodarcze przedsiębiorstw. Warsaw: PWE.

28. Lissowski, O. (2014). Kierunki modernizacji zarządzania publicznego. In: S. Lachiewicz, B. Nogalski (eds.), Osiagnięcia i perspektywy nauk o zarzadzaniu. Warsaw: Oficyna a Wolters Kluwer Business.

29. Mandell, M.P., Keast, R. (2008). Evaluating the effectiveness of interorganizational relations through networks. Developing a framework for revised performance measures. Public Management Review, 10(6).

30. Mazur, S., Olejniczak, K. (2012). Rola organizacyjnego uczenia się we współczesnym zarządzaniu publicznym. In: K. Olejniczak (ed.), Organizacje uczace się. Model dla administracji publicznej. Warsaw: Wydawnictwo Naukowe Scholar.

31. Mazur, S. (2015). Współzarządzanie a administracja publiczna. In: S. Mazur (ed.), Wspótzarządzanie publiczne. Warsaw: Wydawnictwo Naukowe SCHOLAR.

32. Morawska, S., Kuczewska, J. (2016). Propozycja benchmarkingu sieci współpracy organizacji wymiaru sprawiedliwości. In: P. Banasik, R. Sobiecki (eds.), Wymiar sprawiedliwości $w$ dobie oczekiwań społecznych, cz. II. Zarzadzanie i ekonomia. Warsaw: Beck.

33. Müller-Seitz, G. (2012). Leadership in Interorganizational Networks: A Literature Review and Suggestions for Future Research. International Journal of Management Reviews, 14. 
34. Nogalski, B., Dwojacki, P. (1998). Tworzenie struktur sieciowych jako wynik restrukturyzacji scentralizowanego przedsiębiorstwa. Przegląd Organizacji, 4.

35. Odlanicka-Poczobutt, M. (2011a). Identyfikacja więzi organizacyjnych w strukturach sieciowych i logistycznych w wybranym przedsiębiorstwie. In: R. Borowiecki, T. Rojek (eds.), Procesy formowania więzi organizacyjnych we współczesnej gospodarce. Integracja - kooperencja-klastering (pp. 343-354). Kraków: Fundacja Uniwersytetu Ekonomicznego w Krakowie.

36. Odlanicka-Poczobutt, M. (2011b). Zastosowanie metody B2C dla wspomagania procesów logistycznej obsługi klienta w wybranym przedsiębiorstwie. Zeszyty Naukowe Politechniki Śląskiej, Seria: Organizacja i Zarządzanie, z. 56, 195-214.

37. Odlanicka-Poczobutt, M. (2013). Reorganizacja sądów rejonowych jako element równoważenia sieci. In: A. Karbownik (ed.), Paradygmat sieciowy. Wyzwania dla teorii i praktyki zarządzania (pp. 346-365). Gliwice: Wydaw. Politechniki Śląskiej.

38. Odlanicka-Poczobutt, M. (2016). Modele procesów logistycznych w sądownictwie powszechnym. Gliwice: Wydawnictwo Politechniki Śląskiej.

39. Pniewski, P., Bagińska, A. (2013). Rola facylitatora w metodzie Kręgów Naprawczych Dominica Bartera. Mediator, nr 65(2). Warsaw: Polskie Centrum Mediacji, 4-6.

40. Prawo telekomunikacyjne określone w ustawie z dnia 16 lipca 2004 r. (Dz.U. Nr 171, poz. 1800).

41. Provan, K.G., Milward, H.B. (2001). Do networks really work? A framework for evaluating public sector organizational networks. Public Administration Review, 61.

42. Stabryła, A. (2012). Podstawy organizacji i zarządzania. Kraków: Wydawnictwo Uniwersytetu Ekonomicznego w Krakowie, 62.

43. Szplit, A. Szplit, M. (2014). Paradygmat zarządzania wobec wyzwań nowej ekonomii instytucjonalnej i ładu gospodarczego teorii ordo. Studia i Prace Kolegium Zarzadzania i Finansów SGH, nr 135, 9-19.

44. Tubielewicz, A. (2013). Koncepcja tworzenia organizacji sieciowej. Efektywność, produktywność i organizacja przedsiębiorstw. Zarzadzanie Przedsiębiorstwem, 36, 387-397.

45. Turek, D. (2011). Sprawiedliwość organizacyjna w przedsiębiorstwie. Kwartalnik Nauk o Przedsiębiorstwie, 1, 41-45.

46. Ustawa z dnia 27 lipca 2001 r. Prawo o ustroju sądów powszechnych.

47. Wagner III, J.A., Hollenbeck, J.R. (2010). Organizational Behavior. New York: Routledge, 165.

48. Zawadzak, T. (2014). Zarzadzanie w organizacjach sektora publicznego. Warsaw: Difin. 